\title{
Urban context and neighbouring lands: how reforestation could have a role in the implementation of Sustainable Energy and Climate Action Plans
}

\author{
Simona Abbate ${ }^{1, *}$, Luca Di Paolo ${ }^{1}$, Roberto Carapellucci ${ }^{1}$, and Roberto Cipollone ${ }^{1}$ \\ ${ }^{1}$ Department of Information Engineering and Economics, University of L'Aquila Via G.Gronchi 18. \\ 67100 L'Aquila, Italy
}

\begin{abstract}
Reforestation is the appropriate natural tool to mitigate the climate change. The authors illustrate how to manage cuts and plantations of trees making profit from unused lands, to reach different carbon capture goals. Unused lands, moreover, are frequently in the neighbouring of Municipalities which often are politically responsible of these territories. Their destination as carbon sink inside the implementation of the Sustainable Energy and Climate Action Plans (SECAPs) is particularly suitable, participating in a synergic way to reduce the $\mathrm{CO}_{2}$ municipal emissions by 55 $\%$ in 2030 with respect to the 1990 datum. In the framework of a SECAP, this level is mandatory and participates to the common huge effort to decarbonize energy needs. After having modelled some intrinsic aspects related to the dynamics of the carbon capture due to the growth of trees, the research demonstrated how, with a proper management of cuts and plantations, a new concept of mutualism between city and territory can be designed, recognizing the crucial role of neighbouring unused lands alongside those direct actions usually implemented to reduce the carbon intensity of a city.
\end{abstract}

Introduction Urban areas are responsible for almost $80 \%$ of total GHG [1], so recognising the central role of Municipalities, the importance of the sustainable energy action plans (SEAPs) and subsequent sustainable energy and climate action plans (SECAPs) [2]. To reduce the majority of GHG emissions, interventions should be used in urban context and the most important one appears to be the reforestation [3],[4]. According to the Paris Agreement about the safeguard limit of $450 \mathrm{ppm}$ of $\mathrm{CO}_{2}$ in the atmosphere, forests are the green lung of the world and play an important role in climate mitigation limiting the rise of mean temperature below $2^{\circ} \mathrm{C}$ [5]. A decisive help could be given by the sequestration of the $\mathrm{CO}_{2}$ from the atmosphere; the least expensive way is to store it inside the wood of the forest, according to a suitable management of them. This storage will offer more time to develop new low carbon technologies, renewable energy generation and also awareness and lifestyles based on a more responsible behaviour [6]. It is important to remark that this carbon storage will be only temporary because all the carbon absorbed by the atmosphere during growing

*Corresponding author: simona.abbate@graduate.univaq.it 
will be definitively released again in the atmosphere when forestry material will be cut and put back in carbon cycle. So, the storage will only allow to take time to delay the reaching of the mentioned limit waiting for a more sustainable future. Other side advantages associated with reforestation are related to the more general land management: protection from soil erosion, from landslides, from extreme rainfall, landscape restoration, mitigation of high temperatures, reconstruction of biodiversity which all together affect a more sustainable environment, but the carbon sequestration is only limited in time. It is in the Authors' opinion that today the unused land management in urban contexts finalized to carbon capture and sequestration has a formidable role to help local politically recognized communities (Municipalities) to participate to the international commitments, giving their contribution exactly following a bottom-up approach.

In 2020, with the Green Deal [7], the EU leaders have agreed on an ambitious goal for cutting greenhouse gases, reducing them by $55 \%$ within 2030 against $1990 \mathrm{CO}_{2}$ emissions level and achieving climate neutrality by 2050 making, in this way, more severe these commitments with respect to what agreed only a few years ago. The Land Use, Land Use Change and Forestry sector's emissions and removals has been fully integrated into the proposed 2030 EU greenhouse gas target as reported under the UNFCCC inventory [8]. Agriculture, Forestry and Other Land Use (AFOLU) activities emitted about 25\% of global annual greenhouse gas emission (GHG) [9],[10]. In 2019 the IPCC in the Special Report "Climate Change and Land" highlighted the key role of land-based mitigation and land-use change in fighting climate change, both as carbon sink and contrast to desertification and soil erosion [11],[12]: the biogeochemical cycle of $\mathrm{CO}_{2}$ is heavily affected by forestry [13] whose management and conditions lead the role of forest ecosystems as sink or source of GHGs.

In this work, starting from previous work on Avezzano's SEAP [14], the use of trees, urban forests and green area has been introduced non only to respect the international objective, but to mitigate the erosion by rain, the heat waves and improve the quality of life too. This study has a goal in line with the Green Deal [8],[7]: using forest to mitigate the greenhouse gas emissions by human activity and to achieve the international target. It's easy to know the numbers of emissions in a single city, SEAPs and SECAPs elaboration and monitoring give us some information about the development and the action determined by the Municipalities [2]. They are required to produce a forecast of greenhouse gas emissions and to elaborate some development and mitigation scenarios.

The authors introduce a new concept to analyse the territory: the mutualism between city and territory. Avezzano is the largest city in the Marsica region, the production centre of the area, the economic and commercial hub. The resident population of the region generally works in Avezzano, so the idea is: Avezzano offers works and economic growth to those who live in a neighbouring village, so the neighbouring small city has to bear the burden of the emissions. For this reasons Ortucchio, Trasacco, Pescina, Aielli, Cerchio, Luco dei Marsi, San Benedetto Dei Marsi and Celano which are small cities in the neighbouring of Avezzano must implement some mitigation and reduction actions in synergy with the municipality of the main city, i.e. Avezzano.

In the paper 3 situations called "Pniec" [15], "Europe" [8],[7] and "Constant" are analysed. In the first, the evolution of Avezzano's emissions is simulated respecting the percentages of reduction previewed in the Italian Energy and Climate Plane [15]; the second simulate the evolution of the emissions based on the European's goals. A further analysis provides for the creation of a permanent sink based not on a trend of emissions, but to rake the carbon dioxide from production processes in which technological development has not allowed total decarbonisation. The management of crops includes two possible scenarios: emergency and constant-rate; crop rotation of the first scenario maximizes the absorption in the minor time, instead in constant scenario it creates a permanent adsorption. The authors have been developed a simple model that permits to optimize the management of a unit of 
surface of land, in terms of plantings, cuts and spatial partitions, using a genetic algorithm. There are two different targets: insure the maximum carbon uptake in the minor time (emergency scenario) and guarantees a fairly constant rate of carbon uptake (constant-rate scenario).

\section{Materials and Methods}

\subsection{Assumptions}

To evaluate the capacity of a forest to uptake carbon and reduce the carbon emissions of the area a model has been developed to describe the performance over time of the forest. To calculate the carbon uptake the IPCC approach [16] has been adopted, evaluating the overall biomass growth and using the specific carbon fraction coefficient. Firstly, the Verhulst approach has been used to represent trees growth [17], which are consequently modelled by a logistic curve [18], [19]. Furthermore, forest management in terms of rotation crops has been modelled following two different goals: maximize carbon uptake and obtain a constant uptake rate. Knowing the national and international scenarios and goals, it has been possible evaluate the relevance of reforestation.

\subsection{Tree growth model description}

Data about growth of trees have been taken from the National Forest Inventory and Forest Reservoirs (INFC) [20]. In this paper, data about Abruzzo Region have been considered, mediating the national value on the regional trend in case of missing regional data. The chosen database allows to achieve a highly detailed level, defined as Tier 3 by IPCC guideline. In this work the most common species have been chosen (Scots Pine, Oak and Beech), representing a starting point for future studies in which the best native species, respecting biodiversity, should be analysed. Table 1 shows the raw data provided by INFC database: both tree density and increment of merchantable volume have been successively used as input data for the growth model proposed.

Table 1 Trees density and merchantable tree volume (m3/ha) disaggregated into ages groups (data processed from INFC database), [20]

\begin{tabular}{cccccccccc}
\hline & \multicolumn{2}{c}{ Number of trees } & \multicolumn{6}{c}{ Increment of merchantable tree volume $\left(\mathrm{m}^{3} / \mathrm{ha}\right)$} \\
\hline & trees & trees/ha & $\begin{array}{c}0-10 \\
\text { years }\end{array}$ & $\begin{array}{c}11-20 \\
\text { years }\end{array}$ & $\begin{array}{c}21-30 \\
\text { years }\end{array}$ & $\begin{array}{c}31-40 \\
\text { years }\end{array}$ & $\begin{array}{c}41-80 \\
\text { years }\end{array}$ & $\begin{array}{c}81-100 \\
\text { years }\end{array}$ \\
\hline $\begin{array}{c}\text { Scots } \\
\text { Pine }\end{array}$ & 1403672 & 1189 & 3 & 4.3 & 4.8 & 5.7 & 6.2 & 7 \\
Oak & 107217430 & 1168 & 1.5 & 2.5 & 3.5 & 3.9 & 3.5 & 2.5 \\
Beech & 208708432 & 1577 & 0.5 & 1.5 & 4.2 & 8.1 & 7.5 & 6.2 \\
\hline
\end{tabular}

The eq. (1) represents the analytical expression of logistic growth, [4]:

$$
A G B(t)=\frac{W_{0} \cdot W_{i n f}}{W_{0}+\left(W_{i n f}-W_{0}\right) \cdot e^{-K t}}
$$

where $A G B(t)$ is the tree biomass expressed in $t /$ ha, whereas $W_{\text {inf, }} W_{0}$, and $K$ are logistic parameters, specific for each species, that represent respectively the limit value of $\operatorname{AGB}(\mathrm{t})$, 
the biomass (in $\mathrm{kg}$ or $\mathrm{kg} / \mathrm{ha}$ ) at year zero, and the initial growth rate. Table 2 summarizes values of logistic parameters, estimated starting from real measured data and employing fitting methods.

Table 2 Characteristic parameters of the logistic curve

\begin{tabular}{cccc}
\hline Tree type & $\mathrm{W}_{0}$ & $\mathrm{~W}_{\text {inf }}$ & $\mathrm{k}$ \\
\hline Scots pine & 1.06 & 150 & 0.11 \\
Beech & 0.18 & 140 & 0.14 \\
Oak & 0.74 & 129 & 0.12 \\
\hline
\end{tabular}

Figure 1, referred to scots pine, shows differences between real and logistic growth curve in a range of 100 years. It is clear how the tree growth model matches closely the real growth rate, reaching a maximum difference of $30 \%$ that is completely acceptable considering the complexity of the real AGB process.

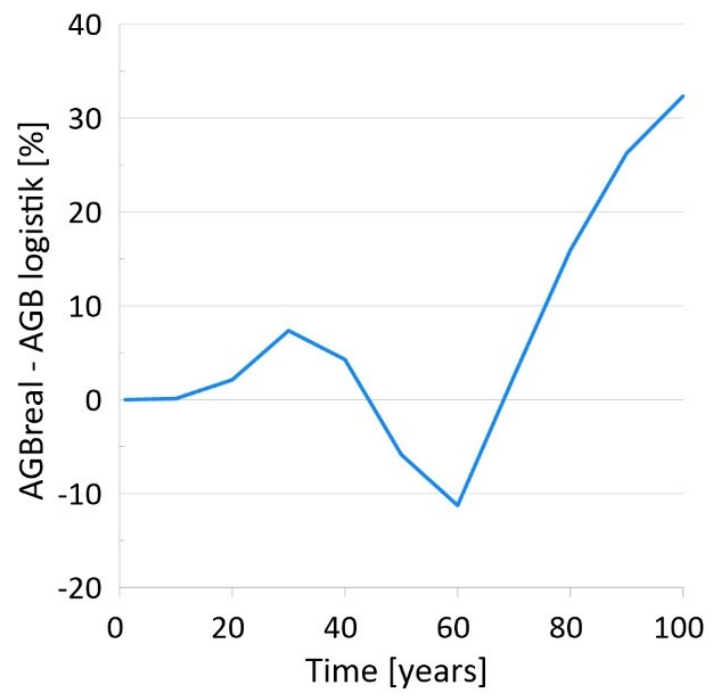

Figure 1 Percentage difference between real and logistic trend in case of scots pine

Subsequently, tree growth model has been completed calculating trend of growth rate during years. It is expressed in terms of CAI (Current Annual Increment) and MAI (Mean Annual Increment), both expressed in $t$ / (ha - year). The CAI is the differential form of the logistic curve, calculated through eq. (2), instead the MAI is the mean value of growth rate.

$$
C A I(t)=\frac{d A G B(t)}{d t}=\frac{W_{i n f} \cdot K \cdot\left(W_{i n f} / W_{0}-1\right) \cdot e^{-K t}}{\left[1+\left(W_{i n f} / W_{0}-1\right) \cdot e^{-K t}\right]^{2}}
$$

being $\mathrm{W}_{0}, \mathrm{~W}_{\text {inf }}$ and $\mathrm{K}$ the same parameters described for Eq. (1). 
Figure 2, referred to scots pine, shows the complete growth model: the logistic growth trend of AGB (blue bar), the CAI (red line) with a typically like bell trend, and MAI (dotted line) that is the medium value of the red line.

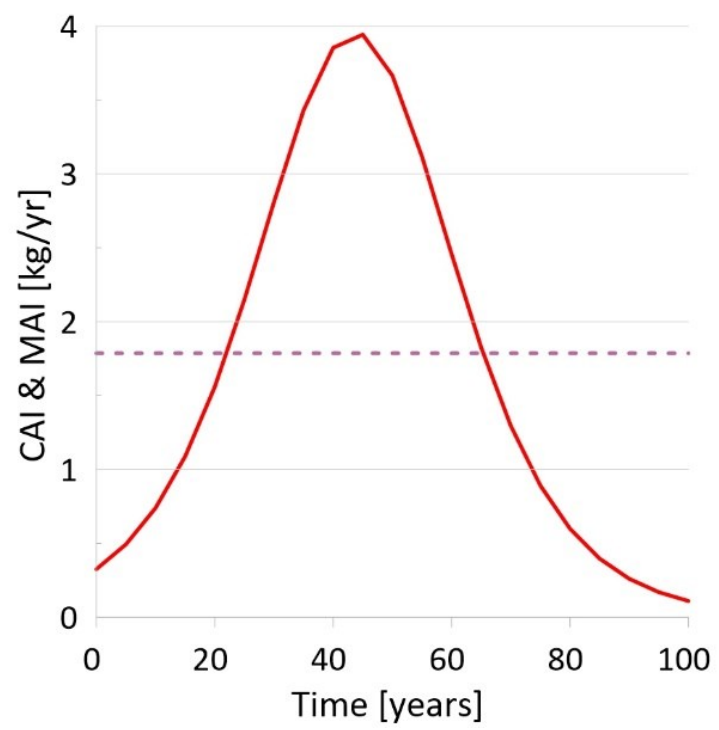

a)

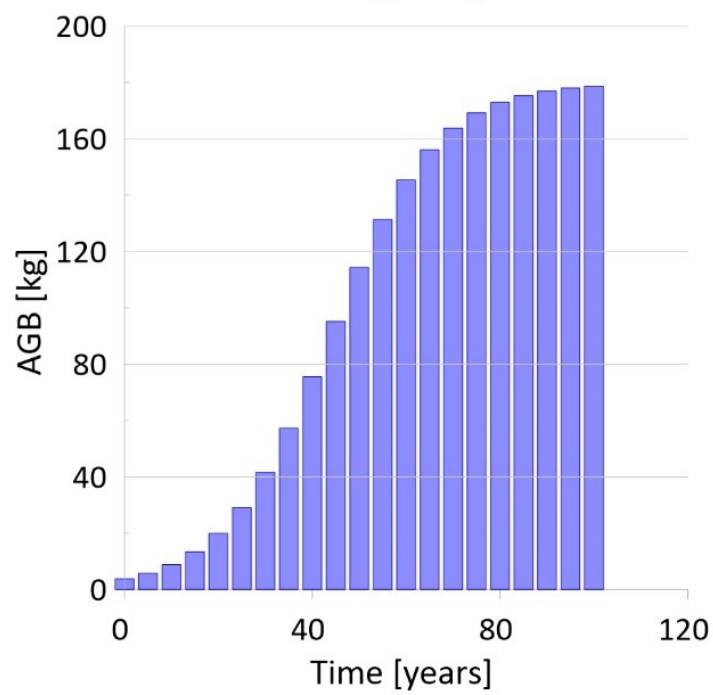

b)

Figure 2 a) CAI and MAI, b) Total AGB, both referred to Scots Pine.

Finally, trees carbon uptake in absolute terms ( $\mathrm{tC} / \mathrm{ha})$ and annual rate $(\mathrm{tC} /(\mathrm{ha} \cdot \mathrm{yr}))$ have been quantified following the IPCC approach [16], by multiplying respectively the values of ABG and CAI by the Carbon Fraction (CF) that represent the portion of carbon inside the biomass (Table 3). 
Table 3 Values of CF [20] and mean carbon uptake carried out by trees growth model.

\begin{tabular}{ccc}
\hline Tree type & CF [21] & $\begin{array}{c}\text { C } \\
{[\mathrm{tC} /(\text { ha } y r)]}\end{array}$ \\
\hline Scots pine & 0.51 & 1.45 \\
Beech & 0.48 & 1.71 \\
Oak & 0.48 & 1.17 \\
\hline
\end{tabular}

Table 3 also summarizes the results carried out by trees growth model in terms of carbon uptake during 100 years period. The values obtained are in line with those reported in literature: many authors [4],[22] suggest values for biomass in the range 0.5-2 tC/(ha $\cdot \mathrm{yr})$.

\subsection{Case study description}

The aim of this scientific research has been to identify a model of management of unused land in Avezzano's area to achieve two basic targets: maximum carbon uptake in a given period of time (emergency scenario) or constant uptake rate during time (constant-rate scenario). The optimization has been carried out through a genetic algorithm developed in an Excel-VBA environment, able to apply the stochastic methodology proposed by Holland [23], [24] and built following the mechanism of biological evolution [25]. The genetic algorithm allows to generate solutions optimizing the parameters by iterations and selection based on Darwin's theory of evolution [26]. Two scenarios have been investigated for the optimization: emergency and constant-rate scenarios. The first applies when the need is to maximize the uptake in a minor time, this solution is more important when the need for reduction of emissions is immediate for the health of the local population and to respect the international target. After the specified period, the trend in per capita emissions is expected to decline and the contribution of reforestation will be not necessary. The second one has been called constant-rate because it permits to always adsorb the same quantity of $\mathrm{CO}_{2}$ in a long-time interval, this solution is essential to absorb emissions in sectors that are difficult to decarbonise and that will continue to produce emissions for years to come.

The model and results could be used in an urban contest to reduce the emissions and permit to respect the internationals goals. The logic of this work has been based on considering not only the city, but the neighbouring lands too, a sort of mutualism between production area and its surrounding territories. The production and economic development have a close link with emissions [27],[28]; neighbouring lands benefit from the city's economic development and will be expected to make a significant contribution to the reduction of emissions.

The study has involved 9 municipalities in the Marsica's area, 1 production centre (Avezzano) and 8 neighbouring municipalities. The Marsica is an agricultural area, the cleared area of Fucino's Lake is all cultivated, but $14 \%$ of the agricultural area is unused (4917 ha). Hectares are abandoned, and in this area some trees could be replanted for the mitigation of the emissions. Application of emergency scenarios has been evaluated in 2 situations: Pniec and Europe. The constant-rate scenario has been applied to simulate the absorption of long-term emissions for sectors of difficult decarbonisation.

The Avezzano's trend of emissions, from 1990, increased until 2005 with a value of $195.61 \mathrm{ktCO}_{2 \mathrm{eq}}$ and gradually declined thereafter to $158.5 \mathrm{ktCO}_{2 \mathrm{eq}}$ [14]. This reduction ($19 \%$ ) was possible thanks to the political decisions and to the energetic actions implemented 
in the framework of SEAPs [29], Figure 3. From these values it has been possible to derive the future trend, based on two regulatory requirements: Pniec and Europe. The first one transposes European legislation and produces some national strategies to respect the international goals. The Italian's Pniec is not updated to the last Green New Deal goals, but it is very significant because it formalizes some limits on emissions and gives some economic, politic, and technological strategies to decarbonise the economy and production system. In the case of Europe, all the ambitious environmental goals have been accepted, even if not formalized yet. In both situations the emergency scenario has been applied.

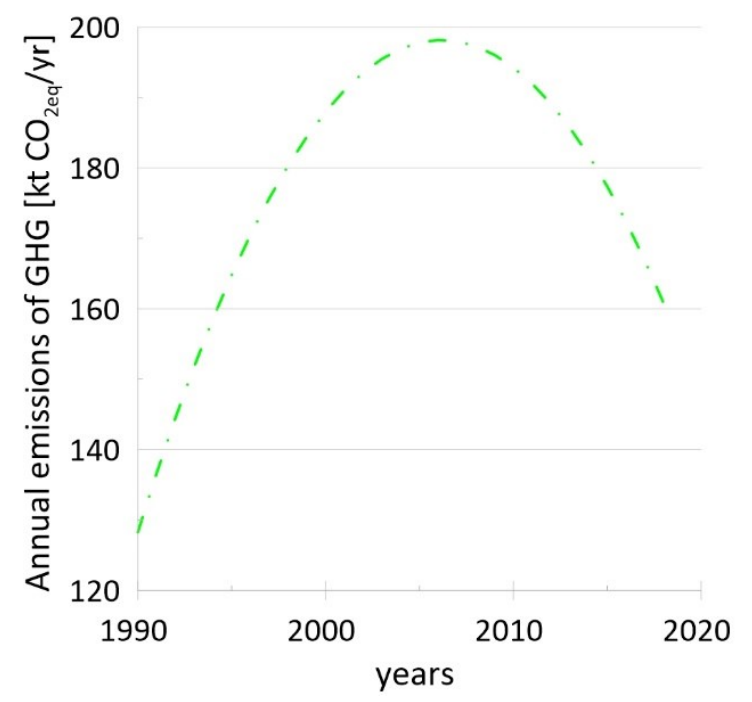

Figure 3 Avezzano's trend of emissions in 1990-2018

\section{Results}

\subsection{Two basic scenarios}

The model shown in the previous sections has been used to obtain the characteristic trends in two basic scenarios considered, the emergency one and the constant-rate one.

\section{Emergency scenario:}

In this case all the trees must be planted in the same year. Figure 4 shows the situation in a time interval of 50 (figure a) and 75 years (figure b). The annual carbon uptake rate (red line) increases till to the maximum value around 40 years. In the case of 50 years the total carbon uptake (blue area) shows a linear trend of growth; when the period is 75 years, the total uptake rate following a logistic curve, after 40 years the annual carbon uptake starts to decrease (red line) but the integral remains growing and reach its maximum value (blue area). The maximum annual uptake rate is the same for both periods considered (Table 4) instead the value of total uptake grows up from $91 \mathrm{tC}$ to $134.2 \mathrm{tC}$ for a single hectare.

The model has permitted to evaluate the situation after 100 years, this interval of time involves a cut and a rotation of crops. This situation lies outside the scope of this study because the emergency scenario is an immediate response to a problem of emissions. 
European targets provide zero emissions in 2050, so considered larger time interval is not functional for the solution of the problem.

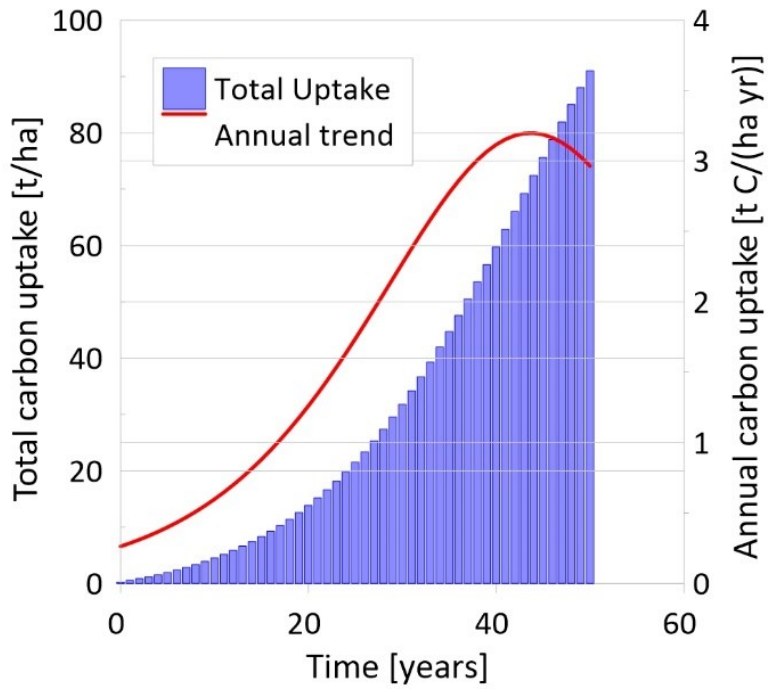

a)

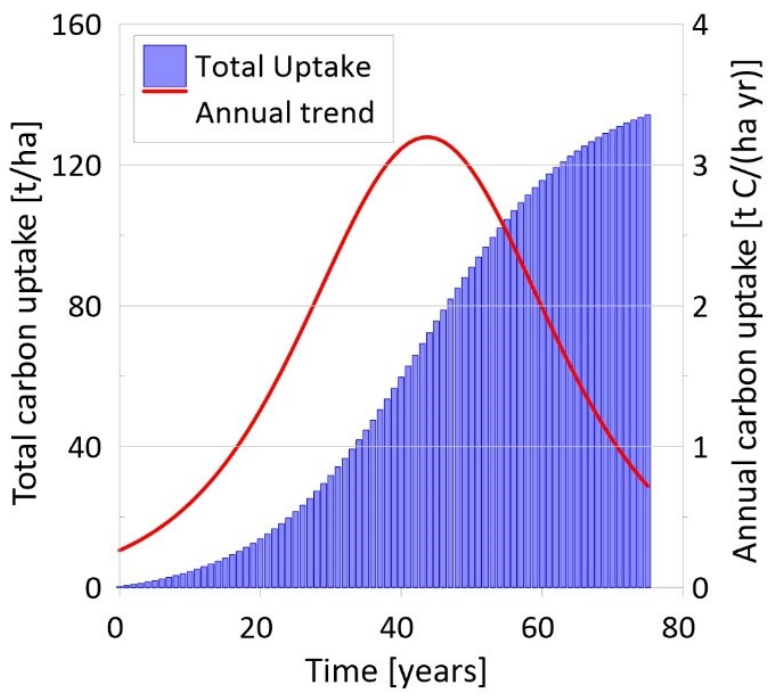

b)

Figure 4 Emergency scenario, trend is related to the individual hectare. The red line represents the annual carbon uptake the blue area represents the total uptake. Emergency scenario applied to a) 50 years and b) 75 years.

Table 4 Maximum value of uptake and total uptake for a single hectare in emergency scenarios with 50 and 75 years periods.

\begin{tabular}{lll}
\hline Scenarios & $\begin{array}{c}\text { Maximum annual } \\
\text { uptake } \\
{[\mathrm{t} \mathrm{C} /(\mathrm{yr} \mathrm{ha})]}\end{array}$ & $\begin{array}{l}\text { Total uptake } \\
{[\mathrm{t} \mathrm{C} / \mathrm{ha}]}\end{array}$ \\
\hline Emergency 50 & 3.20 & 91.0
\end{tabular}




\section{Constant-rate scenario:}

This scenario supposed that the uptake trend has been constant over a long period of time, but for this reason the first 20 years should be excluded in the process of optimization because they represent the inertial trend of the initial plantation phase, so the objective of the optimization has been to minimize the variance of the curve after 20 years. For a period of 150 years the optimal management of the single hectare provides a division of the surface in 4 equal parts. All trees are planted in the first year but, after 28 years, $1 / 4$ of hectare is cut and replanted (rotation 1); after 5 years (33 years from the beginning) another fourth of hectare is cut and replanted (rotation 2). This continues after 25 years ( 58 years from the first year) (rotation 3 ) and again after 16 years (74 years from the beginning) (rotation 4) (Figure 5). All the plantations are left growing till to the same residual carbon uptake rate is reached $(0.21 \mathrm{t}$ $\mathrm{C} / \mathrm{yr}$ ), at this value the rotation is cut and replanted. The temporal interval of rotation 1 and 2 is less than 5 years, so for a better and easier management of the land a simplification factor has been introduced. Hence rotations 1 and 2 have been considered in the same year, assuming the time of cut and planting in the middle of the two time-lags; the hectare provides a division of the whole area in 4 parts yet, but the first and second fractions are cut and replanted after 30 years together, Figure 5 . The results of this solution have been reported in Table 5, after 150 years the total uptake is $250.4 \mathrm{tC}$ (blue area Figure $6 \mathrm{~b}$ ) and the value of the medium uptake (blue line Figure 6 a) is $1.82 \mathrm{tC} / \mathrm{yr}$ for 1 hectare.

Table 5 Data of the constant scenario.

\begin{tabular}{lccc}
\hline Scenarios & $\begin{array}{c}\text { Maximum swing } \\
\text { uptake }[\mathrm{tC} /(\mathrm{yr} \text { ha })]\end{array}$ & $\begin{array}{c}\text { Medium uptake } \\
{[\mathrm{tC} /(\mathrm{yr} \text { ha })]}\end{array}$ & $\begin{array}{c}\text { Total uptake } \\
{[\mathrm{t} \mathrm{C} / \mathrm{ha}]}\end{array}$ \\
\hline Constant & 0.90 & 1.82 & 250.4 \\
\hline
\end{tabular}




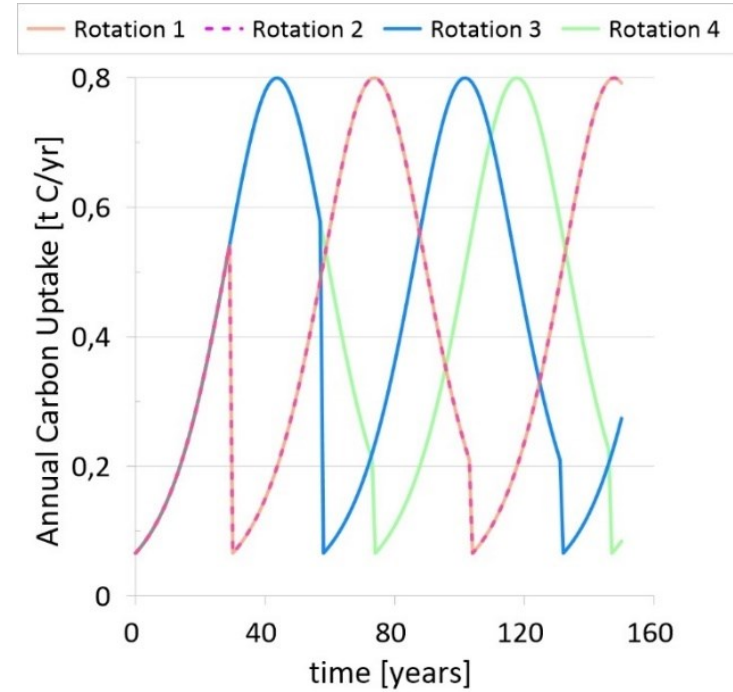

Figure 5 Constant scenario obtained minimizing variance. The rotation 2 coincides with the rotation 1 because the time interval is shorter than 5 years or shorter of it. The vertical lines is the cut of a single rotation, all the plantations are left growing till to the same residual carbon uptake rate is reached $(0.21$ $\mathrm{t} \mathrm{C/yr),} \mathrm{at} \mathrm{this} \mathrm{value} \mathrm{the} \mathrm{rotation} \mathrm{is} \mathrm{cut} \mathrm{and} \mathrm{replanted.} \mathrm{The} \mathrm{annual} \mathrm{carbon} \mathrm{uptake} \mathrm{of} \mathrm{each} \mathrm{rotation} \mathrm{is}$ referred to $1 / 4$ of a hectare. 


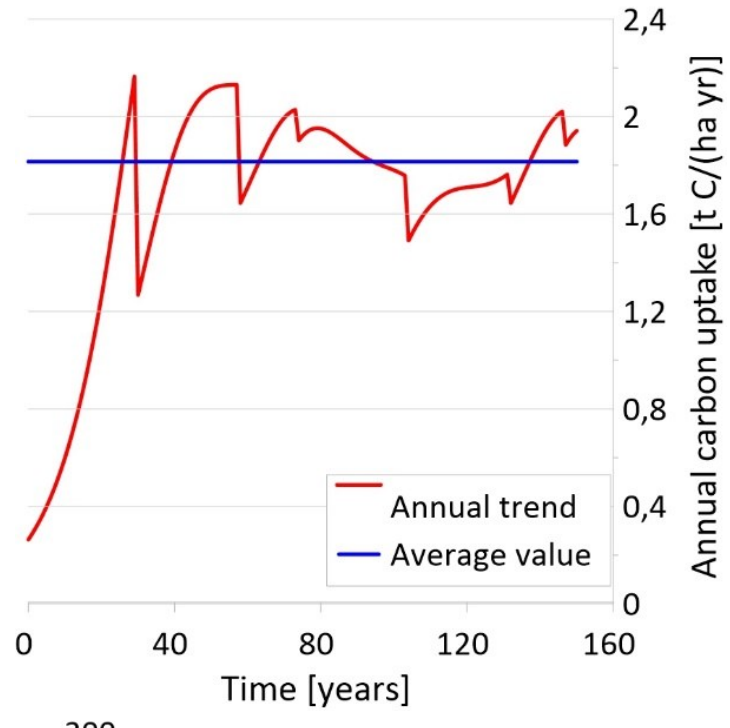

a)

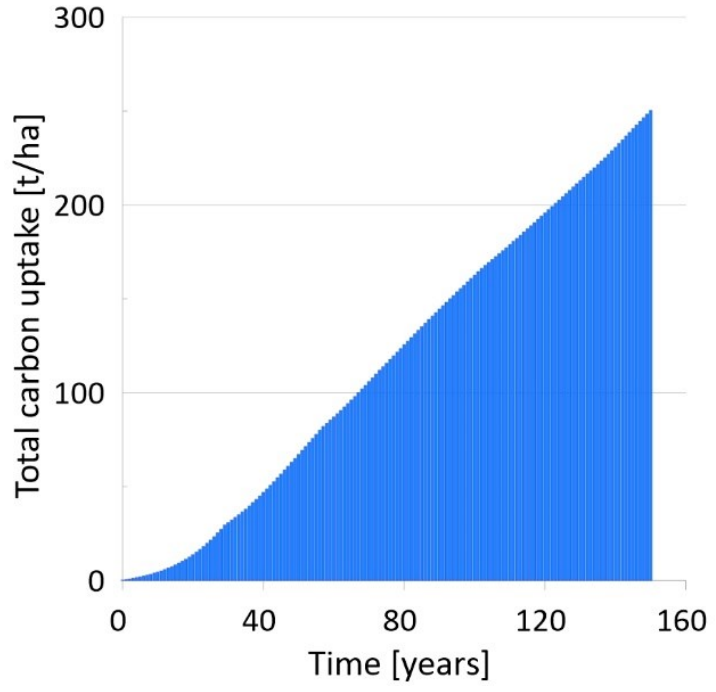

b)

Figure 6 Constant scenario, trend is related to the individual hectare. a) annual uptake, the red line represents the annual carbon uptake; b) total carbon uptake.

\subsection{Case study}

\section{“PNIEC" case:}

In this case the Italian's scenarios of emission reported in Integrated National Energy and Climate Plan (PNIEC) [15] have been utilized. This scenario predicts that, in Italy, emissions 
will fall off from $581 \mathrm{MtCO}_{2 \text { eq }}$ in 2005 to $367 \mathrm{MtCO}_{2 \text { eq }}$ in 2040 , a reduction of $37 \%$, as detailed in Table 6 distinguishing contributions from energy and other sources.

Table 6 Trend of emissions in Italy, PNIEC [15]

\begin{tabular}{ccccccccc}
\hline $\begin{array}{c}\text { Emissions of } \\
\begin{array}{c}\mathrm{GHG} \\
{\left[\mathrm{MtCO} \mathrm{eq}_{\mathrm{e}} \mathrm{yr}\right]}\end{array}\end{array}$ & 2005 & 2010 & 2015 & 2020 & 2025 & 2030 & 2035 & 2040 \\
\hline $\begin{array}{c}\text { From energy } \\
\text { consumption } \\
\text { From other } \\
\text { sources }\end{array}$ & 480 & 417 & 353 & 341 & 324 & 312 & 304 & 297 \\
\hline Total & $\mathbf{5 8 1}$ & $\mathbf{5 0 4}$ & $\mathbf{4 3 3}$ & $\mathbf{4 1 9}$ & $\mathbf{3 9 9}$ & $\mathbf{3 8 4}$ & $\mathbf{3 7 3}$ & $\mathbf{3 6 7}$ \\
\hline $\begin{array}{c}\text { \% of reductio } \\
\text { respect } 2005\end{array}$ & - & -13 & -25 & -28 & -31 & -34 & -36 & -37 \\
\hline
\end{tabular}

Considering the Avezzano's area, emissions until 2018 represent the real trend, calculated in the SEAPs monitoring process and reported in Figure 3, while from 2020 to 2040 the trend has been derived applying the same percentage of reduction present in PNIEC. The total trend is represented in Figure 7, the maximum value of emissions is $196 \mathrm{ktCO}_{2 \mathrm{eq}}$ in 2005 and the minimum value is $124 \mathrm{ktCO}_{2 \text { eq }}$ reached in 2040 with a percentage of reduction of $37 \%$ referred to 2005 (Table 7).

Table 7 Trend of annual $\mathrm{CO}_{2}$ emissions in Avezzano. Data 1990-2018 are real data from SECAPs and monitoring [29] [14], instead data 2020-2040 reflect the PNIEC trend.

\begin{tabular}{lccc|ccccc}
\hline & 1990 & 2005 & 2018 & 2020 & 2025 & 2030 & 2035 & 2040 \\
\hline $\begin{array}{l}\text { Emissions of GHG } \\
{[\mathrm{ktCO} \text { eq/yr] }}\end{array}$ & 126.2 & 195.6 & 158.5 & 141.1 & 134.3 & 129.3 & 125.6 & 123.6 \\
$\begin{array}{l}\text { \% of reduction } \\
\text { respect 2005 }\end{array}$ & - & - & -19 & -28 & -31 & -34 & -36 & -37 \\
\hline
\end{tabular}




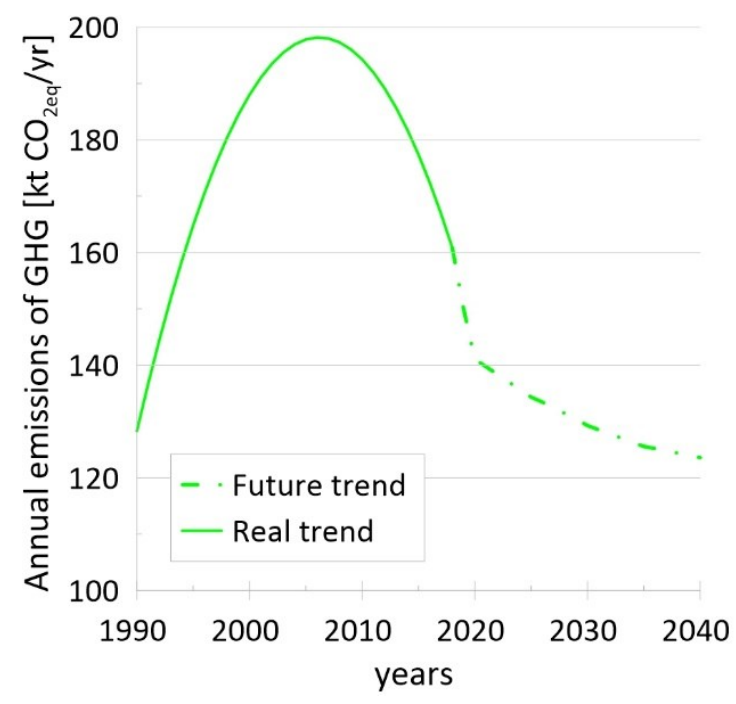

Figure 7 Trend of emissions in Avezzano. Data 1990-2018 are real data (solid line) from SECAPs and monitoring [29] [14], instead data 2020-2040 reflect the PNIEC trend (dashed line)

The PNIEC case is illustrated in Figure 7. In this situation an operation of reforestation could be executed with the emergency scenario. The total agricultural unused land in Avezzano is 4917 ha: considering a reforestation of pine, the reduction of emission ranges from a value of 3\% in 2021 to a value of $17 \%$ in 2040. As shown in Figure 8, the amount of avoided $\mathrm{CO}_{2 \mathrm{eq}}$ emissions is in the range $0-21 \mathrm{kt} \mathrm{CO} 2 / \mathrm{yr}$. The cumulative emissions without reforestation in 2040 are $2740 \mathrm{ktCO}_{2 \mathrm{eq}}$, instead with reforestation the total emissions at the end of the period of observation are $2514 \mathrm{ktCO}_{2 \text { eq. }}$. The quantity of total $\mathrm{CO}_{2 \text { eq }}$ not emitted in 20 years is $227 \mathrm{kt} \mathrm{CO}_{2}$ Table 8 .

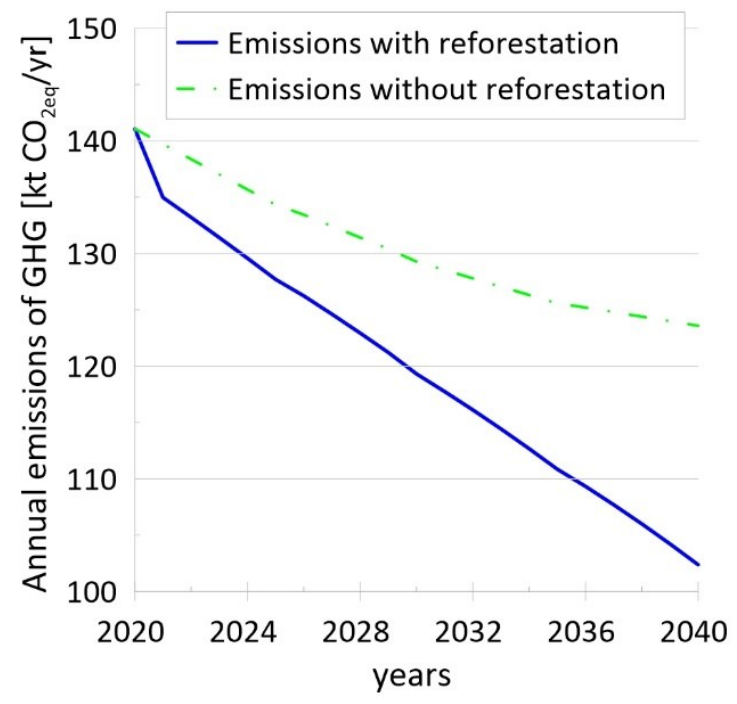

Figure 8 Trend of annual $\mathrm{CO}_{2}$ emissions in Avezzano from 2020 to 2040, PNIEC. The green dashed line represents the original trend instead the blue line the trend with reforestation. 
Table 8 Annual and total uptake in PNIEC case

\begin{tabular}{cccccc|ccc}
\hline & 2020 & 2025 & 2030 & 2040 & 2050 & 2030 & 2040 & 2050 \\
Annual uptake $\left[\mathrm{kt} \mathrm{CO}_{2} / \mathrm{yr}\right]$ & & \multicolumn{2}{c|}{$\begin{array}{c}\text { Total } \\
\text { Uptake }\left[\mathrm{kt} \mathrm{CO}_{2}\right]\end{array}$} \\
\hline $\begin{array}{c}\text { PNIEC } \\
\text { PNIEC with } \\
\text { reforestation }\end{array}$ & 141 & 134 & 129 & 124 & - & 1483 & 2740 & - \\
\hline $\begin{array}{c}\mathrm{CO}_{2} \text { not } \\
\text { emitted }\end{array}$ & 0 & 7 & 10 & 21 & - & 71 & 227 & - \\
\hline
\end{tabular}

\section{“EUROPE” case:}

Applying all the strictest limits discussed, some not yet approved, referred to the GHG emissions, it has been possible to reconstruct the emissions trend in Avezzano. Unlike the previous case, in which the PNIEC considers technological development and economical trend, in this case a picture of emissions has been made to respect the international intentions without a concrete analysis of the real possibility of implementation.

The new proposal [7] foresees 2 goals in 2030 and another in 2050. In the first year a reduction of 55\% compared with 1990 levels will be obtained, in the second the achievement of zero emissions will be reached. This value applied in Avezzano returns the value reported in Table 9.

Table 9 Trend of annual $\mathrm{CO}_{2}$ emissions in Avezzano. Data 1990-2018 are real data from SECAPs and monitoring [29] [14], instead data 2020-2040 reflect the EUROPE trend.

\begin{tabular}{cccc|ccc}
\hline & 1990 & 2005 & 2018 & 2020 & 2030 & 2050 \\
\hline $\begin{array}{c}\text { Emissions of } \\
\text { GHG }\end{array}$ & 126.2 & 195.6 & 158.5 & 142.1 & 56.8 & 0 \\
$\begin{array}{c}{\left[\mathrm{ktCO}_{2 \mathrm{eq}} / \mathrm{yr}\right]} \\
\% \text { Of reduction } \\
\text { respect } 1990\end{array}$ & - & +55 & +26 & +13 & -55 & -100 \\
\hline
\end{tabular}

Considering the total unutilised surface of 4917 ha and an intervention of reforestation with the emergency scenario, the carbon neutrality is achieved in 2041-2042, about ten years before the international target (Figure 9). From 2042 the function of the forest in the study area is done, this must not become a pretext to slow the energy transition, because the forest continues to adsorb the GHG from the atmosphere and permits to reduce the total global emissions.

The annual $\mathrm{CO}_{2 \text { eq }}$ emissions could be reduced in the range 0-39 $\mathrm{kt} \mathrm{CO}_{2 \mathrm{eq}} / \mathrm{yr}$ and the total $\mathrm{CO}_{2 \text { eq }}$ emissions pass from $1634 \mathrm{ktCO}_{2 \text { eq }}$ in 2020 to $1101 \mathrm{ktCO}_{2 \text { eq }}$ in 2050 , a $32 \%$ reduction (Table 10). 


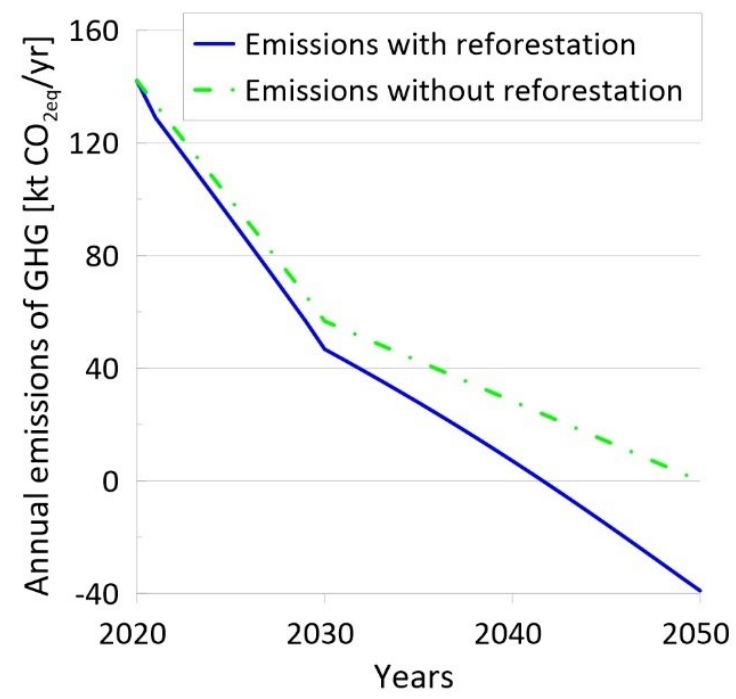

Figure 9 Trend of annual $\mathrm{CO}_{2}$ emissions in Avezzano from 2020 to 2050, "EUROPE" case. The green dashed line represents the original trend instead the blue line the trend with reforestation.

Table 10 Annual and total uptake in "Europe" case

\begin{tabular}{cccccc|ccc}
\hline & 2020 & 2025 & 2030 & 2040 & 2050 & \multicolumn{2}{c}{$\begin{array}{c}2030 \\
\text { Total }\end{array}$} & $\begin{array}{c}2040 \\
\text { Uptake } \mathrm{kt}^{\left.\mathrm{CO}_{2}\right]}\end{array}$ \\
\hline $\begin{array}{c}\text { EUROPE } \\
\text { Annual uptake }\left[\mathrm{kt} \mathrm{CO}_{2} / \mathrm{yr}\right]\end{array}$ & 142 & 100 & 57 & 28 & 0 & 1096 & 1507 & 1634 \\
$\begin{array}{c}\text { EUROPE with } \\
\text { reforestation }\end{array}$ & 142 & 93 & 47 & 7 & -39 & 1025 & 1280 & 1101 \\
\hline $\begin{array}{c}\mathrm{CO}_{2} \text { not } \\
\text { emitted }\end{array}$ & 0 & 7 & 10 & 21 & 39 & 71 & 227 & 533 \\
\hline
\end{tabular}

\section{Constant-rate case:}

This case study allows to simulate a scenario in which the $\mathrm{EU} \mathrm{CO} \mathrm{CO}_{2}$ emission target by 2050 is not achieved, due to the existence of production processes in which technological development has not allowed total decarbonisation. In particular, the annual $\mathrm{CO}_{2}$ emission related to the above-mentioned production processes have been quantified as the $15 \%$ of the total emission in 1990, while the remainder $85 \%$ follows a reduction rate in line with the EU target (European Trend). To quantify these considerations for Avezzano city, Table 11 summarizes the emission data $\left(\mathrm{kt} \mathrm{CO}_{2}\right)$ and shows a residual value amount to $18.93 \mathrm{ktCO}_{2}$ eq. The $\mathrm{CO}_{2}$ emission trend of Avezzano from 1990 to 2170 is illustrated in Figure 10.

Table 11 Trend of annual $\mathrm{CO}_{2}$ emissions in Avezzano. Data 1990-2018 are real data from SECAPs and monitoring [24] [14], instead data 2020-2170 reflect a "EUROPE" trend which considers residual emission related to production processes hardly to be decarbonised.

\begin{tabular}{ccccccc}
\hline & 1990 & 2005 & 2018 & 2030 & 2050 & 2170 \\
\hline $\begin{array}{c}\text { Emissions of GHG } \\
{\left[\mathrm{ktCO} \text { eq }_{\text {/yr }]}\right.}\end{array}$ & 126.2 & 195.6 & 158.5 & 67,2 & 18,93 & 18,93 \\
\hline
\end{tabular}




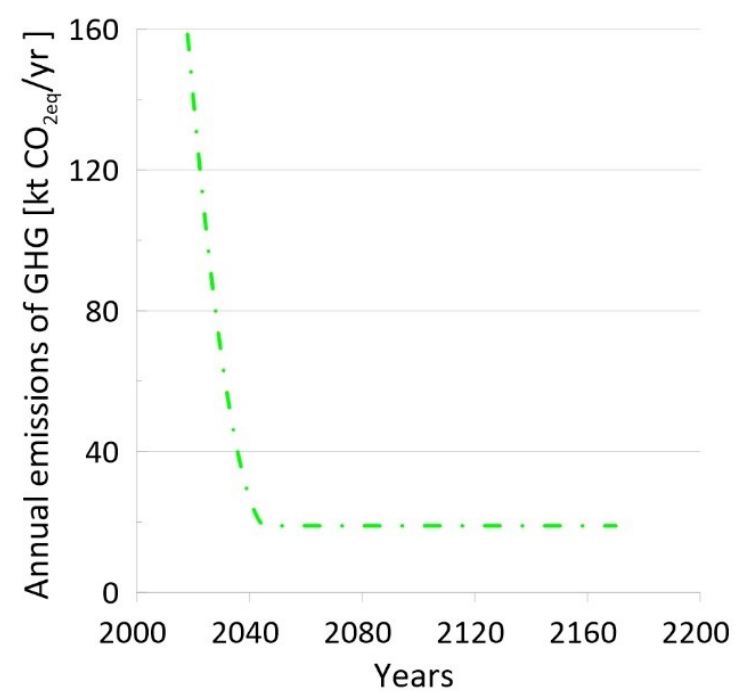

Figure 10 Annual emission trend of $\mathrm{CO}_{2}$ from 1990 to 2170, considering residual emission related to production processes hardly to decarbonised.

From Figure 10, for mitigating $\mathrm{CO}_{2}$ emissions in the scenario described above a carbon sink that ensures a constant uptake trend over a long period of time is necessary. This may be achieved by choosing the rotations strategy described in previous paragraphs and called "constant-rate scenario". In particular, taking into consideration the numerical information shown in Figure 5 and Figure 6, the effect of reforestation with a "constant-rate scenario" rotations management has been simulated starting from 2018. Furthermore, to ensure the reaching of zero emission target in 2050 an area of 4072.11 ha is required. In particular Figure 11 and Figure 12 show the effect of reforestation in terms of annual and cumulative $\mathrm{CO}_{2}$ emission. 


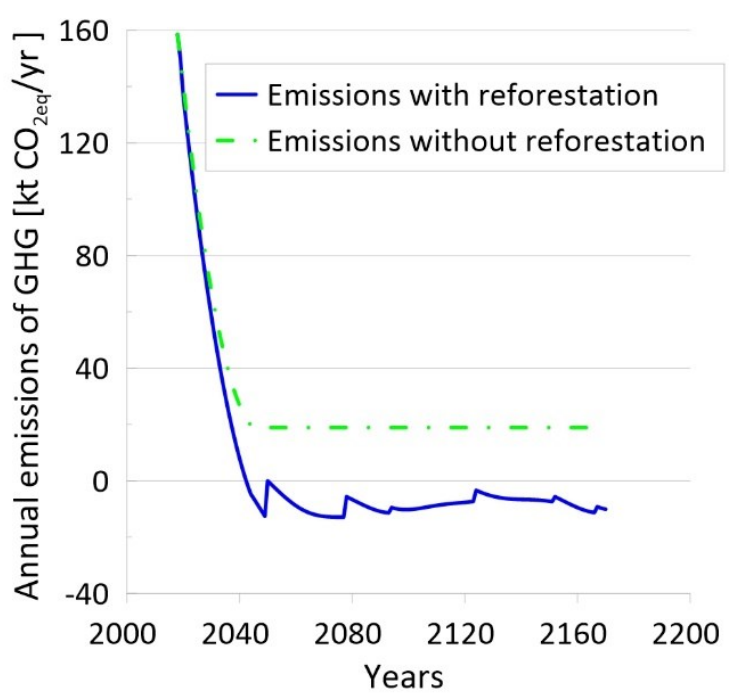

Figure 11 Trend of annual CO2 emissions in Avezzano from 2018 to 2170, constant-rate case. The green dashed line represents the original trend instead the blue line the trend with reforestation.

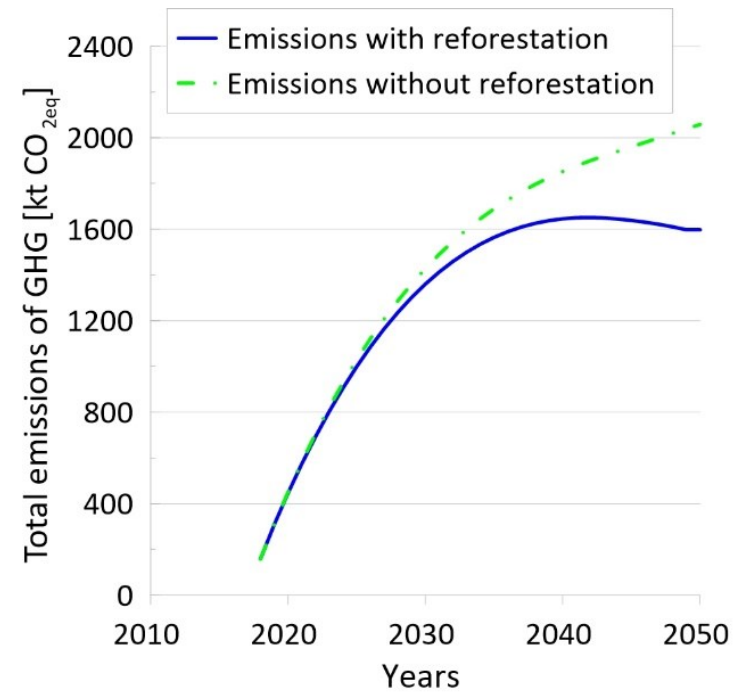

Figure 12 Total CO2 emissions in Avezzano from 2018 to 2050, constant-rate case. The green dashed line represents the original trend instead the blue line the trend with reforestation.

The total $\mathrm{CO}_{2 \text { eq }}$ net emissions pass from $2057 \mathrm{ktCO}_{2 \text { eq }}$ in 2018 to $1597 \mathrm{ktCO}_{2 \text { eq }}$ in 2050 . This $22 \%$ reduction in 2020 (Figure 12 and Table 12) tends to decrease slightly during the following years.

Table 12 Annual and total uptake in constant-rate case

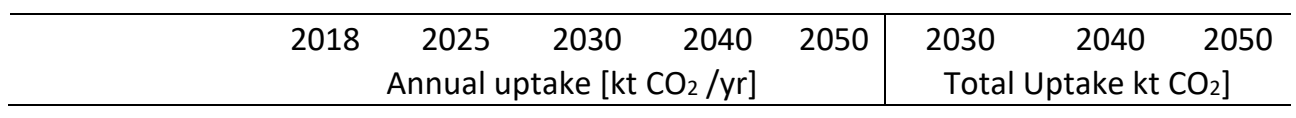




\begin{tabular}{cccccc|ccc}
\hline $\begin{array}{c}\text { Constant } \\
\begin{array}{c}\text { Constant with } \\
\text { reforestation }\end{array}\end{array}$ & 158 & 100 & 67 & 26 & 18 & 1427 & 1852 & 2057 \\
\hline $\begin{array}{c}\mathrm{CO}_{2} \text { not } \\
\text { emitted }\end{array}$ & 0 & 6 & 9 & 18 & 18 & 68 & 207 & 460 \\
\hline
\end{tabular}

\section{Conclusion}

The work assessed the potential offered by reforestation as a carbon sink to reach the $\mathrm{EU} \mathrm{CO}_{2}$ emission target in the Municipal context. In particular the carbon uptake dynamics has been highlighted, exploring the key role of the management of cuts and reforestation of trees with reference to lands not interested to agricultural needs (unused land). The paper has been introduced a new approach, considering not only the city but the neighbouring lands too: in fact, neighbouring territories benefit from the city's economic development and will be expected to give a significant contribution to the reduction of emissions.

Different situations have been analysed. The effect of reforestation in Pniec and Europe cases is noticeable: planting all the unused land in the Marsica region the reduction of emissions, with respect to current levels, will be above $15 \%$ in 2040 around $28 \%$ in 2050 . The "constant-rate scenario" represents an important instrument for political and scientific perspectives because it allows to create a constant sink; policy makers could decide which sectors decarbonise later and scientists have more time to study innovative technique to decarbonize the society. If $15 \%$ of the Avezzano's emissions in 1990 cannot be removed, to achieve the carbon neutrality in 2050 it is necessary to plant about 4070 ha in 2020.

In urban context, the reference made to unused lands in surrounding of Cities allows to plan a more strategic reforestation project. In fact, from an integrated point of view reforestation acts not only as carbon sink, but also as protection tools against environmental issues that will be more enhanced by climate change: soil erosion, landslides, extreme rainfall, landscape restoration, mitigation of high temperatures, reconstruction of biodiversity.

\section{Bibliography}

[1] C. Schenone, I. Delponte, I. Pittaluga, The preparation of the Sustainable Energy Action Plan as a city-level tool for sustainability: The case of Genoa, J. Renew. Sustain. Energy. 7 (2015). https://doi.org/10.1063/1.4921723.

[2] C. of M. European Commission, Data about SECAPs and SEAP, (2020). https://www.covenantofmayors.eu/en/.

[3] D.J. Nowak, D.E. Crane, Carbon storage and sequestration by urban trees in the USA, n.d. www.elsevier.com/locate/envpol.

[4] F.P. Nicese, G. Colangelo, R. Comolli, L. Azzini, S. Lucchetti, P.A. Marziliano, G. Sanesi, Estimating CO2 balance through the Life Cycle Assessment prism: A case Study in an urban park, Urban For. Urban Green. (2020). https://doi.org/10.1016/j.ufug.2020.126869.

[5] P. Lauri, N. Forsell, A. Korosuo, P. Havlík, M. Obersteiner, A. Nordin, Impact of the $2{ }^{\circ} \mathrm{C}$ target on global woody biomass use, For. Policy Econ. 83 (2017) 121-130. https://doi.org/10.1016/j.forpol.2017.07.005.

[6] B.K. Sovacool, How long will it take? Conceptualizing the temporal dynamics of energy transitions, Energy Res. Soc. Sci. 13 (2016) 202-215. https://doi.org/10.1016/j.erss.2015.12.020. 
[7] European Commission, Sustainable Europe Investment Plan European - European Green Deal Investment Plan, J. Chem. Inf. Model. 53 (2019) 1689-1699. https://eurlex.europa.eu/legal-content/EN/TXT/PDF/?uri=CELEX:52020DC0021\&from=EN.

[8] European Commission, Stepping up Europe's 2030 climate ambition Investing in a climate-neutral future for the benefit of our people, J. Chem. Inf. Model. 53 (2020) 1689-1699.

[9] C. Poeplau, A. Don, L. Vesterdal, J. Leifeld, B. Van Wesemael, J. Schumacher, A. Gensior, Temporal dynamics of soil organic carbon after land-use change in the temperate zone - carbon response functions as a model approach, Glob. Chang. Biol. 17 (2011) 2415-2427. https://doi.org/10.1111/j.1365-2486.2011.02408.x.

[10] M.V. Chiriacò, R. Valentini, A land-based approach for climate change mitigation in the livestock sector, J. Clean. Prod. 283 (2021). https://doi.org/10.1016/j.jclepro.2020.124622.

[11] FAO, Recarbonitation of global soils, (2019).

[12] A. Rivera, C. Bravo, G. Buob, Climate Change and Land Ice, 2017. https://doi.org/10.1002/9781118786352.wbieg0538.

[13] E. Eriksson, A.R. Gillespie, L. Gustavsson, O. Langvall, M. Olsson, R. Sathre, J. Stendahl, Integrated carbon analysis of forest management practices and wood substitution, Can. J. For. Res. 37 (2007) 671-681. https://doi.org/10.1139/X06-257.

[14] A. Cinocca, L. Di Paolo, S. Abbate, R. Cipollone, Methodologies for Sustainable Energy Action Plan design and monitoring applied to the Municipality of Avezzano, Abruzzo Region, Italy, E3S Web Conf. 197 (2020). https://doi.org/10.1051/e3sconf/202019708013.

[15] Ministry of Economic Development, Ministry of the Environment and Protection of Natural Resources and the Sea, Ministry of Infrastructure and Transport, INTEGRATED NATIONAL ENERGY AND CLIMATE Ministry of Economic Development, (2019).

[16] K.T. and F.W. Jim Penman, Michael Gytarsky, Taka Hiraishi, Thelma Krug, Dina Kruger, Riitta Pipatti, Leandro Buendia, Kyoko Miwa, Todd Ngara, IPCC, Good Practice Guidance for Land Use, Land-Use Change and Forestry, 2015. https://doi.org/10.1016/j.crvi.2014.11.004.

[17] D. Ditto, M. Acutis, S. Bocchi, Attuale stato dell'analisi funzionale della crescita delle piante Veneto Regional Environment Energy, Special Projects Office View project Beyond Classical Growth Models in Biology View project, 2010. https://www.researchgate.net/publication/256780084.

[18] B. Zeide, Analysis of Growth Equations, For. Sci. 39 (1993) 594-616. https://doi.org/10.1093/forestscience/39.3.594.

[19] V.H. Dale, T.W. Doyle, H.H. Shugart, A comparison of tree growth models, 1985.

[20] INFC, Inventario Nazionale delle Foreste e dei serbatoi forestali di Carbonio INFC2005 Tabella 3 . 4 . 2 - Valori totali e per unità di superficie del numero totale di soggetti della rinnovazione per le categorie forestali dei Boschi alti ( parte 1 di 6 ) Bosc, d (2005) 2-9.

[21] N.T. and T.K. (eds) Eggleston H.S., Buendia L., Miwa K., 2006 IPCC Guidelines for National Greenhouse Gas Inventories, (2006).

[22] U.S. Enviromental Protection Agency, Greenhouse Gas Mitigation Potential in U.S. Forestry and Agriculture, (2005).

[23] J.H. Holland, Adaptation in natural and artificial systems : an introductory analysis with applications to biology, control, and artificial intelligence, Ann Arbor Univ. $\begin{array}{llllll}\text { Michigan } & \text { Press } & \text { (1975) } & \text { viii, } & 183 & \text { p. }\end{array}$ http://mitpress.mit.edu/catalog/item/default.asp?ttype=2\&tid=8929.

[24] J.H. Goldberg, David E and Holland, Genetic algorithms and machine learning, 
Kluwer Acad. Publ. Publ. 19 (1988) 117-119.

[25] R. Carapellucci, L. Giordano, A Genetic Algorithm for Optimizing Heat Recovery Steam Generators of Combined Cycle Power Plants., ASME Int. Mech. Eng. Congr. Expo. 54907 (n.d.) 121-130. https://doi.org/doi:10.1115/IMECE2011-63703, ISBN: 978-0-7918-5490-7.

[26] R. Carapellucci, L. Giordano, A methodology for the synthetic generation of hourly wind speed time series based on some known aggregate input data, Appl. Energy. 101 (2013) 541-550. https://doi.org/10.1016/j.apenergy.2012.06.044.

[27] M. Tucker, Carbon dioxide emissions and global GDP, Ecol. Econ. 15 (1995) 215223. https://doi.org/10.1016/0921-8009(95)00045-3.

[28] J.G. Canadell, C. Le Quéré, M.R. Raupach, C.B. Field, E.T. Buitenhuis, P. Ciais, T.J. Conway, N.P. Gillett, R.A. Houghton, G. Marland, Contributions to accelerating atmospheric $\mathrm{CO} 2$ growth from economic activity, carbon intensity, and efficiency of natural sinks, Proc. Natl. Acad. Sci. U. S. A. 104 (2007) 18866-18870. https://doi.org/10.1073/pnas.0702737104.

[29] Provincia dell'Aquila, SEAP Avezzano, covenant of mayors, (2013). https://mycovenant.eumayors.eu/docs/seap/2656_1348844661.pdf. 